\title{
NOTE
}

\section{Selection of brood stock candidates of barfin flounder using an ELISA system with recombinant protein of barfin flounder nervous necrosis virus}

\author{
Ken-ichi Watanabe ${ }^{1, *}$, Toyohiko Nishizawa ${ }^{2}$, Mamoru Yoshimizu $^{3}$ \\ ${ }^{1}$ Akkeshi Station of the Japan Sea-Farming Association, Akkeshi 088-1108, Japan \\ ${ }^{2}$ Applied Biological Science, Hiroshima University, Higashi-Hiroshima 739-8528, Japan \\ ${ }^{3}$ Faculty of Fisheries, Hokkaido University, Hakodate 041-8611, Japan
}

\begin{abstract}
Barfin flounder nervous necrosis virus (BFNNV), the causative agent of viral nervous necrosis (VNN) of barfin flounder, is vertically transmitted from spawners to larvae. In the present study, an ELISA with a recombinant protein of BFNNV was performed for the detection of antibodies against. BFNNV and applied for the selection of brood fish in order to prevent viral vertical transmissions. Brood stocks were divided into 4 groups based on ELISA antibody titers $(\leq 10,20$, 40 and $>40$ ), and the BFNNV status of the brood stocks was determined by PCR. BFNNV was detected from the brood fish in the group with an antibody titer of $>40$ but not from those with titers $\leq 10,20$ and 40 . The offspring obtained from PCRnegative brood fish pairs in each group of ELISA antibody titers were subsequently reared for observation of VNN occurrence. VNN occurred in juveniles from 2 of 9 pairs of spawners with an antibody titer $\geq 40$, but did not occur in spawners with an antibody titer of $\leq 10$. Therefore, it was concluded that selection of brood fish using both the PCR test and ELISA antibody titers could help prevent vertical transmission of BFNNV in larval production of barfin flounder.
\end{abstract}

KEY WORDS: Viral nervous necrosis (VNN) - Barfin flounder nervous necrosis virus (BFNNV) - Selection of brood fish Recombinant protein. ELISA antibody titer

In coastal areas of the northern part of Japan, the population of barfin flounder Verasper moseri has been decreasing. Aquaculture and sea farming of barfin flounder are very important and have expanded because barfin flounder grows rapidly at low temperatures and is a relatively high-price commodity. The Akkeshi Station of the Japan Sea-Farming Association (JASFA) has established larval production and rearing

•E-mail: kenichi-watanabe@jasfa.or.jp methods for barfin flounder. In 1993, mass mortalities occurred in barfin flounder juveniles. The affected fish, which demonstrated abnormal swimming behavior and had eye hemorrhages, were diagnosed as viral nervous necrosis (VNN)-positive by a PCR test and histological and electron microscopical observations (Watanabe et al. 1999). Since the first VNN case was reported in Japanese parrotfish Oplegnathus fasciatus (Yoshikoshi \& Inoue 1990), VNN and similar diseases have been observed worldwide in 22 fish species (Muroga et al. 1998). The causative agent of VNN in barfin flounder, barfin flounder nervous necrosis virus (BFNNV), is a member of fish nodaviruses but genetically distinguishable from a type species of fish nodavirus, striped jack Pseudocaranx dentex nervous necrosis virus (SJNNV) (Mori et al. 1992, Nishizawa et al. 1995,1999 ).

In larval production of striped jack, the selection of spawner based on PCR detection of SJNNV just before spawning is useful in preventing vertical virus transmission (Mushiake et al. 1994). SJNNV was often detected from PCR-negative spawners after repeated experimental spawning and resulted in the occurrence of VNN in their offspring (Mushiake et al. 1993). Thus, larval production in striped jack should be performed with offspring from PCR-negative brood fish which have spawned fewer than 10 times (Mori et al. 1998). In the case of barfin flounder, it was hard to prevent vertical transmission of BFNNV because VNN occurred in larvae around 60 or more days old even though PCRnegative spawners with little spawning experience had been used (Watanabe et al. 1999). This is in contrast to striped jack, and we have concluded that an additional method is therefore needed for the selection of barfin flounder spawners. In the present study, an 
ELISA system using a recombinant coat protein of BFNNV was established to detect antibodies against BFNNV and applied to select spawners based on ELISA antibody titers in order to prevent vertical transmission of BFNNV.

Materials and methods. Antigen for ELISA: A recombinant coat protein of BFNNV was obtained from a culture broth of Escherichia coli strain EX-B203. The T2 region of the BFNNV coat protein gene was amplified from total nucleic acids of infected barfin flounder juveniles by PCR under the same conditions used for fish nodaviruses (Nishizawa et al. 1994). The forward primer, F1-exp, which contained the NdeI site (5'-aacatatagGGATTTGGACGTGCGACCAA-3'), and the reverse primer, $\mathrm{R} 3-\exp$, which contained the InindII site (5'-TCTTCACCCGTGTTGACTCGigaagcttagc-3'), were employed for the PCR amplification. The PCR products were digested with NdeI and HindIII and were ligated into the NdeI -HindIII site of the pET-25b (+) expression vector (Novagen) to transform the $E$. coli strain BL21 (DH3) according to the instructions of the manufacturer. The transformed $E$. coli EX-B203 was cultured at $37^{\circ} \mathrm{C}$ until optical density $\left(O D_{600}\right)$ reached 0.4 to 0.6 in Luria-Bertani (LB) broth (1\% Bacto tryptone, $0.5 \%$ yeast extract, $1 \% \mathrm{NaCl}$, $\mathrm{pH}$ 7.5) containing $50 \mathrm{mg} \mathrm{ml}^{-1}$ ampicillin. Expression products from the $\mathrm{T} 2$ region of BFNNV in the plasmid were induced by the addition of $1 \mathrm{mM}$ isopropyl $\beta$-Dthiogalactopyranoside (IPTG) to $E$. coli cells. Following incubation at $37^{\circ} \mathrm{C}$ for $2.5 \mathrm{~h}$, the cells were washed and resuspended in $50 \mathrm{mM}$ Tris- $\mathrm{HCl}(\mathrm{pH} 8.0)$ and $2 \mathrm{mM}$ EDTA. After the addition of $100 \mathrm{mg} \mathrm{ml}^{-1}$ lysozyme and $0.1 \%$ Triton $\mathrm{X}-100$, the cell suspension was incubated at $30^{\circ} \mathrm{C}$ for $15 \mathrm{~min}$, ultrasonicated, and centrifuged at low speed $(300 \times g)$ for $15 \mathrm{~min}$. The pellet and supernatant were harvested as insoluble and soluble induced fractions, respectively. The obtained fractions were analyzed by $12 \%$ polyacrylamide gel electrophoresis (PAGE) under the reducing conditions of Laemmli (1970), and proteins in a gel were electroblotted to the nitrocellulose membrane using the procedure of Towbin et al. (1979). Proteins on the nitrocellulose membrane were detected using rabbit serum against SJNNV, horseradish peroxidase (HRP)-conjugated antibody against rabbit immunogloblin and the HRP development kit (BioRad).

ELISA system for detection of fish antibody: ELISA plates (Greiner) were coated overnight at $4{ }^{\circ} \mathrm{C}$ by adding $50 \mu \mathrm{l}_{\text {well }} \mathrm{l}^{-1}\left(10 \mu \mathrm{g} \mathrm{m}^{-1}\right)$ of purified SJNNV particles (kindly provided by Dr M. Arimoto, Kamiura Station, JASFA) or recombinant coat protein of BFNNV (in carbonate-bicarbonate buffer, $\mathrm{pH} \mathrm{9.6).} \mathrm{The} \mathrm{plate}$ was washed 3 times with PBS containing $0.05 \%$ Tween 20 (PBST) and blocked with $2 \%$ skim-milk in PBST at $37^{\circ} \mathrm{C}$ for $1 \mathrm{~h}$. After washing in PBST 3 times, diluted fish sera were added and incubated at $37^{\circ} \mathrm{C}$ for $2 \mathrm{~h}$. The plate was washed 3 times with PBST and then rabbit serum against barfin flounder IgM was added and incubated at $37^{\circ} \mathrm{C}$ for $1 \mathrm{~h}$. The fish IgM binding to the antigen was detected with a HRP-conjugated antibody against rabbit immunogloblin (DAKO) and o-phenylenediamine. The ELISA absorbance was measured by a spectrophotometer at $\mathrm{OD}_{492}$. ELISA antibody titer is defined as the maximum dilution of serum in which the absorbance values reach baseline absorbance (Yoshimizu et al. 1998). Sera from brooders were diluted from $1: 10$ to $1: 2560$ to determine ELISA antibody titers and baseline absorbance. The baseline absorbance was approximately 0.01 in our system.

Grouping of brood fish and larval production: Individuaily identified brooders (131 males and $66 \mathrm{fe}-$ males) distinguished by Pit Tags (diameter: $2 \mathrm{~mm} \times$ $11 \mathrm{~mm}$, Kawamura-tsusho) were divided into 4 groups based on ELISA antibody titer against BFNNV: the titers $\leq 10,20,40$ and $>40$. ELISA was performed 3 mo before spawning. The BFNNV status of all brood fish was determined with a PCR test using their sperm and ovarian fluid. The PCR-negative sperm and ovarian fluid from some pairs of brooders which had had few spawning experiences in each ELISA group were used for artificial fertilizations. The fertilized eggs were disinfected with ozonated seawater $\left(0.5 \mathrm{mg} \mathrm{l}^{-1}, 5 \mathrm{~min}\right)$ in the morula stage (Watanabe \& Yoshimizu 1998). Some larvae obtained from each brooder pair were subjected to PCR detection of BFNNV at $5 \mathrm{~d}$ intervals for more than $60 \mathrm{~d}$ rearing. The PCR detection of BFNNV was performed as described previously (Nishizawa et al. 1994).

Results and discussion. The results of SDS-PAGE and Western blot analyses of soluble and insoluble fractions of Escherichia coli EX-B203 are shown in Fig. 1. There was more expressed protein from the $\mathrm{T} 2$ region of $B F N N V$ in the insoluble fraction than in the soluble one. The expressed protein immunostained with antiserum against SJNNV was approximately $32 \mathrm{kDa}$ and was consistent with the estimated size based on the amino acid sequence encoded in the T2 region of BFNNV (Nishizawa et al. 1995). Approximately $700 \mathrm{mg}$ of the recombinant protein from the BFNNV T2 region was obtained by a 11 culture broth of $E$. coli EX-B203. To compare the antigenicity between the recombinant protein of BFNNV and the native coat protein of SJNNV, 40 times diluted sera from 7 antibody-positive barfin flounders were used for ELISA. There was not much difference in ELISA absorbance values between the 2 capture antigens, and it was confirmed again that BFNNV and SJNNV coat proteins shared common antigens (Table 1). BFNNV and SJNNV are serologically distinguishable from each other by monoclonal antibodies against 
from the present results that the risk of viral vertical transmission is greatly decreased by brood fish selection based on both PCR assay and antibody detection.

In general, the detection of fish antibodies against fish pathogens has not been accepted as a routine detection method for assessing the viral and bacterial status in fish populations (Thoesen 1994, OIE 1997). However, there are many reports of the detection of antibodies against fish viruses, such as the Egtved virus (Olesen et al. 1991), spring viremia of carp virus (Dixon et al. 1994), infectious pancreatic necrosis virus (Dixon \& De Groot 1996) and lymphocystis virus (Lorenzen \& Dixon 1991, Dixon et al. 1996, Nishida et al. 1998). In a case of VNN on striped jack, a single examination of plasma antibody just before spawning was found to be useless for the selection of virus-tree spawners because there was no correlation between the presence of antigen in the ovary and the presence of antibody in plasma (Mushiake et al. 1992). Conversely, an ELISA system to detect antibody against nodavirus of sea bass Dicentrarchus labrax was useful for screening spawners for the purpose of preventing vertical virus transmission (Breuil \& Romenstand 1999). These different results may be due to differences in fish species and/or type of causative viruses. At least in the case of barfin flounder, VNN has not occurred in larvae and juveniles obtained from spawners with an ELISA antibody titer of $\leq 10$. The annual production of barfin flounder juveniles at the Akkeshi Station of JASFA was less than 10000 after VNN occurred. However it recovered to more than 100000 juveniles after PCR and ELISA antibody titer assays were employed for brood fish selection. Therefore, we believe that selection of brood fish using both assays could more effectively prevent vertical transmission of BFNNV in the larval production of barfin flounder

Acknowledgements. We thank Dr M. Arimoto, manager of the Kamiura Station of the Japan Sea-Farming Association, for providing purified SJNNV We also thank Dr K. Kawamata, senior researcher at the Hokkaido Institute of Mariculture, for his kind help.

\section{LITERATURE CITED}

Breuil G, Romenstant B (1999) A rapid ELISA method for detecting specific antibody level against nodavirus in the serum of the sea bass, Dicentrarchus Iabrax (L.): application to the screening of spawners in a sea bass hatchery. $J$ Fish Dis 22:45-52

Dixon PF, De Groot J (1996) Detection of rainbow trout antibodies to infectious pancreatic necrosis virus by an immunoassay. Dis Aquat Org 26:125-132

Dixon PF, Hattenberger-Baudouy AM, Way K (1994) Detection of carp antibodies to spring viraemia of carp virus by a competitive immunoassay. Dis Aquat Org 19:181-186

Dixon PF, Vethaak D, Bucke D, Nicholson M (1996) Prelimi- nary study of the detection of antibodies to lymphocystis disease virus in flounder, Platichthys flesus L, exposed to contaminated harbor sludge. Fish Shellfish Immunol 6: $123-133$

Laemmli UK (1970) Cleavage of structural protein during the assembly of the head of bacteriophage T4. Nature 227 : $680-685$

Lorenzen N, Dixon PF (1991) Antibody response to VHS virus proteins in rainbow trout. Fish Shellfish Immunol 3: $461-474$

Mori K, Nakai T, Muroga K, Arimoto M, Mushiake K, Furusawa I (1992) Properties for a new virus belonging to nodaviridae found in larval striped jack (Pseudocaranx dentex) with nervous necrosis. Virology 187:368-371

Mori K, Mushiake K, Arimoto M (1998) Control measures for viral nervous necrosis in striped jack. Fish Pathol 33: $443-444$

Muroga K, Furusawa T, Furusawa I (1998) A review: viral nervous necrosis in striped jack, Pseudocaranx dentex. Suisanzosyoku 46:473-480 (in Japanese with English summary)

Mushiake K, Arimoto M, Furusawa T, Furusawa I, Nakai T, Muroga K (1992) Detection of antibody against striped jack nervous necrosis virus (SJNNV) from brood stocks of striped jack. Nippon Suisan Gakkaishi 58:2351-2356

Mushiake K, Nakai T, Muroga, K, Sekiya S, Furusawa I (1993) Viral nervous necrosis (VNN) of striped jack: effects of plasma antibody level of spawners and spawning conditions on the occurrence of the disease in their offsprings. Suisanzosyoku 41:327-332 (in Japanese with English summary)

Mushiake K, Nishizawa T, Nakai T, Furusawa I, Muroga K (1994) Control of VNN in striped jack: selection of spawners based on the detection of SJNNV gene by polymerase chain reaction (PCR). Fish Pathol 29:177-182

Nishida T, Yoshimizu M, Ezura Y (1998) Detection of antibody against lymphocystis disease virus in Japanese flounder by enzyme linked immunosorbent assay. Fish Pathol 33: $207-211$

Nishizawa T, Mori K, Nakai T, Furusawa I, Muroga K (1994) Polymerase chain reaction ( $P C R$ ) amplification of RNA of striped jack nervous necrosis virus (SJNNV). Dis Aquat Org 18:103-107

Nishizawa $T$, Mori $K$, Furuhashi $M$, Nakai $T$, Furusawa I, Muroga K (1995) Comparison of the coat protein genes of five fish nodaviruses, the causative agents of viral nervous necrosis in marine fish. J Gen Virol 76:1563-1569

Nishizawa T, Muroga K, Arimoto M (1996) Failure of the Polymerase Chain Reaction (PCR) method to detect striped jack nervous necrosis virus (SJNNV) in striped jack Pseudocaranx dentex selected as spawners. J Aquat Anim Health 8:332-334

Nishizawa T, Takano R, Muroga K (1999) Mapping the neutralizing epitope on the coat protein of nodavirus, striped jack nervous necrosis virus (SJNNV). J Gen Virol 80 : 3023-3028

Office International des Épizooties (1997) OIE diagnostic manual for aquatic animal diseases. Office International des Épizooties, Paris

Olesen NJ, Lorenzen N, Jorgensen PEV (1991) Detection of rainbow trout antibody to Egtved virus by enzyme-linked immunosorbent assay (ELISA), immunofluorescence (IF). and plaque neutralization tests ( $50 \%$ PNT). Dis Aquat Org $10: 31-38$

Thoesen JC (ed) (1994) Blue book, Ver 1. Suggested procedures for the detection and identification of certain finfish and shellfish pathogens. Fish Health Section, American 
Fisheries Society, Bethesda, MD

Towbin H, Staehelin T, Gordon J (1979) Electrophoretic transfer of proteins from polyacrylamide gels to nitrocellulose sheets: procedure and some applications. Proc Natl Acad Sci USA 76:4350-4354

Watanabe K, Yoshimizu M (1998) Disinfection of equipments for aquaculture and fertilized eggs by ozonated seawater Fish Pathol 33:145-146 (in Japanese with English summary)

Watanabe K, Yoshimizu M (1999) Susceptibility of fish cell line against fish nodavirus. Fish Pathol 34:213-214 (in Japanese with English summary)

Watanabe K, Ishima M, Kawamata K, Yoshimizu M, Ezura $Y$

Editorial responsibility: Jo-Ann Leong,

Corvallis, Oregon, USA
1999) Occurrence of viral nervous necrosis in hatcheryreared barfin flounder. Bull Fac Fish Hokkaido Univ 50: 101-113 (in Japanese with English summary)

Yoshikoshi K, Inoue K (1990) Viral nervous necrosis in Hatchery-reared larvae and juveniles of Japanese parrotfish, Oplegnathus fasciatus (Temminck \& Schlegel). J Fish Dis 13:69-77

Yoshimizu M, Suzuki K, Nishizawa $T$, Winton JR, Ezura $Y$ (1998) Antibody screening for the identification of nervous necrosis virus carriers in a flounder brood stock. In: National Research Institute of Aquaculture (ed) New approaches to viral diseases of aquatic animals. NRIA International Workshop, Nansei, p 124-130

Submitted: August 10, 1999; Accepted: March 16, 2000 Proofs received from author(s): June 30, 2000 